\title{
Pain Signaling and Gangliosides
}

\section{疼痛におけるガングリオシドの機能}

\author{
Watanabe, Shun ${ }^{1}$; and Higashi, Hideyoshi ${ }^{2}$ \\ ${ }^{1}$ Department of Pharmacology, School of Pharmacy, Kitasato University, Minato-ku, Tokyo 108-8641, Japan \\ E-mail: watanabes@pharm.kitasato-u.ac.jp \\ ${ }^{2}$ Division of Glyco-Signal Research, Institute of Molecular Biomembrane and Glycobiology, Tohoku Pharmaceutical University, \\ Sendai, Miyagi, 981-8558, Japan \\ FAX: +81-22-727-0077, E-mail: hhigashi@tohoku-pharm.ac.jp
}

(Received on July 3, 2014, accepted on August 25, 2014)

Key Words: pain, nociception, hyperalgesia, gangliosides, afferent neuron

\begin{abstract}
Pain sensing is an important nervous system function to detect and avoid potentially harmful stimuli. In addition to direct noxious stimuli, inflammation and neuronal damage can also raise sensory nerve activation which is then transmitted to a higher brain region through particular neural pathways. In addition, pain sensing is increased under various physiological or pathological conditions such as viral infection, diabetes, cancer, chronic inflammation, or damage to neuronal fibers. It is possible that pain sensitivity persists long after tissue injury or inflammation has been resolved. In this chronic case, pain is a disease rather than a sign of tissue damage because pain sensitivity without tissue damage is not beneficial in avoidance of further tissue damage. Although the nervous system has abundant gangliosides, which play important roles in neural functions, little is known how gangliosides regulate pain sensing. In this review, we introduce several works that reveal gangliosides modulate pain sensing. These studies involve using naïve animals or pathological animal models. Moreover, we discuss the possibility that peripheral ganglioside GT1b produces nociception and hyperalgesia by regulation of peripheral glutamate signaling.
\end{abstract}

\section{A. The Pain Pathway}

Peripheral nerve fibers innervate skin and sense various extrinsic stimuli such as temperature, touch, itch, and pain. These innervated fibers are connected to receptor cells, form encapsulated nerve endings, or unmyelinated free nerve endings from both unmyelinated and myelinated nerve fibers. Noxious stimuli leads to depolarization in free nerve endings and then nociceptive signals are driven towards central nervous systems. Sensory fibers are divided into $\mathrm{A} \beta$-, $\mathrm{A} \delta$-, and $\mathrm{C}$-fibers according to their diameters and conduction velocity. Nociceptors include part C-fibers and part $\mathrm{A} \delta$ fiber. A $\delta$-fibers which are myelinated, are separated into a highthreshold mechanoreceptive fiber and a mechano-heat sensitive fiber. A $\delta$-fiber activation leads to sharp pricking pain. On the other
要 約

痛みの感受性は潜在的に有害な刺激を発見し、回避する 重要な神経系の機能の一つである。直接的な侵害刺激に加え て、炎症や神経組織への損傷も感覚神経の活性化を引き起こ し、その信号は特定の神経経路を介して脳の高次領域へと伝 達される。さらに、様々な生理的な条件下や、病的な状態 （例えばウィルス感染、糖尿病、がん、慢性的な炎症、神経 繊維への障害など）でも痛みの感受性は増加する。組織への 障害や炎症が完治した後も、痛みの過敏化が持続する可能性 がある。このような慢性的な疼痛の場合、組織障害が伴わな い疼痛はもはやさらなる組織障害を回避するためには役に立 たず、痛みは組織の障害のサインというよりは、病気と言っ て良い状態となる。ガングリオシドは神経細胞に多量に含ま れ、神経系において重要な機能を果たしているが、ガングリ オシドがどのように疼痛を制御しているかについてはほとん ど知られていない。このレビューでは、ガングリオシドが痛 みを調節しうることを述べたいくつかの研究を紹介する。こ れらの研究では、無処置動物や、病的な疼痛モデル動物を使 用している。さらに、最近我々のグループの研究が明らかに した末梢のガングリオシドGT1bが疼痛や痛覚過敏を末梢の グルタミン酸シグナルを介して引き起こすことについて述べ る。

\section{A. 痛みの伝導路}

末梢の神経繊維は皮膚内に侵入し、温度、触覚、痒み、 痛みなど多様な外部の刺激を感知する。これらの皮膚に侵入 した神経繊維は受容器細胞に接続するか、被包性の神経終 末、もしくは無髄化した自由神経終末を形成する。この自由 神経終末は無䯣であるが、無髄、有髄繊維の両者から生じる。 侵害性の刺激は自由神経終末において脱分極を生じさせ、こ の侵害性の信号は中枢神経系へと伝わる。これら感覚性の繊 維は直径と神経伝達速度により $\mathrm{A} \beta$-、 $\mathrm{A} \delta$-、C-繊維などと分 類される。痛みを受容する繊維は $\mathrm{A} \delta$-、C-繊維の一部が担う。 $\mathrm{A} \delta$-繊維は有髄繊維であり、高闇值で機械刺激を受容するも の、温度と機械刺激両者を受容するものに分けられる。 $\mathrm{A} \delta$ 繊維の刺激は“鋭く”“刺すような”痛みとして感じられる。 
hand, most C-fiber nociceptors can respond to noxious thermal, mechanical, and chemical stimuli. Thus, these nociceptors are called polymodal nociceptors. These peripheral neural fibers are from primary afferent neurons which have cell bodies in the dorsal root ganglion (DRG, which is located close to the spinal cord and is a swelling along the dorsal root. Afferent nerve fibers enter the spinal cord through dorsal root). Primary afferent neurons also elongate axons into the spinal dorsal horn and synapse to dorsal horn neurons. The axons of dorsal horn neurons in the pain pathway are projected to a higher brain center through the contralateral spinal cord. At synapses between the primary afferent neurons and the dorsal horn neurons, substance $\mathrm{P}$ and glutamate is used as an excitatory neurotransmitter. In addition, neural fiber projected from higher brain centers to the spinal cord can reduce nociceptive signaling from peripheral to central. For example, periaqueductal grey (PAG) neurons can inhibit spinal nociceptive neuron via rostroventromedial medulla (RVM). Locus coeruleus (LC) neurons are also important in the endogenous anti-nociceptive system. LC neurons inhibit the transmission between primary afferent neurons and spinal dorsal horn neurons (Fig. 1). Moreover, spinal GABAergic and glycinergic interneurons also control pain signaling.

Free nerve endings of primary afferent neurons have many receptors for various endogenous nociceptive agents or nocicep-
一方で、ほとんどのC-繊維は侵害的な熱、機械、化学刺激な ど多様な刺激に反応することができる。そのため、これらの 繊維はポリモーダル受容器とも呼ばれている。以上の末梢神 経繊維はDorsal root ganglion（DRG、後根神経節、脊髄近傍 に位置し、後根の膨らんだ部分である。感覚神経繊維は後根 を通って脊髄へ入る）に細胞体を持つ一次感覚神経由来であ る。一次感覚神経は軸索を脊䯣後角にも伸ばし、後角神経と シナプスを形成する。後角神経の軸索の中で、疼痛を伝達す る軸索は対側の脊髄を通過し、より高次の脳へと投射される。 この後角神経細胞と一次感覚神経との間のシナプスにおいて は、グルタミン酸やサブスタンス $\mathrm{P} か ゙$ 主要な伝達物質として 機能している。さらに、高次脳から脊髄へ投射されている神 経繊維が末梢から中枢への痛みの伝導を減少させる。例えば、 中脳中心灰白質 (periaqueductal grey、PAG) ニューロンは吻 側延髄腹内側部（rostroventromedial medulla、RVM）を介し て脊髄の疼痛の伝導を抑制できる。青斑核（Locus coeruleus、 LC）二ューロンも内在性の疼痛抑制経路として重要である。 青斑核ニューロンは春髄後角に投射し、一次感覚神経と後角 神経間のシナプス伝達などを抑制する（Fig. 1)。さらに、脊 髄の GABA 性とグリシン性の介在神経も痛みのシグナルを調 節できる。

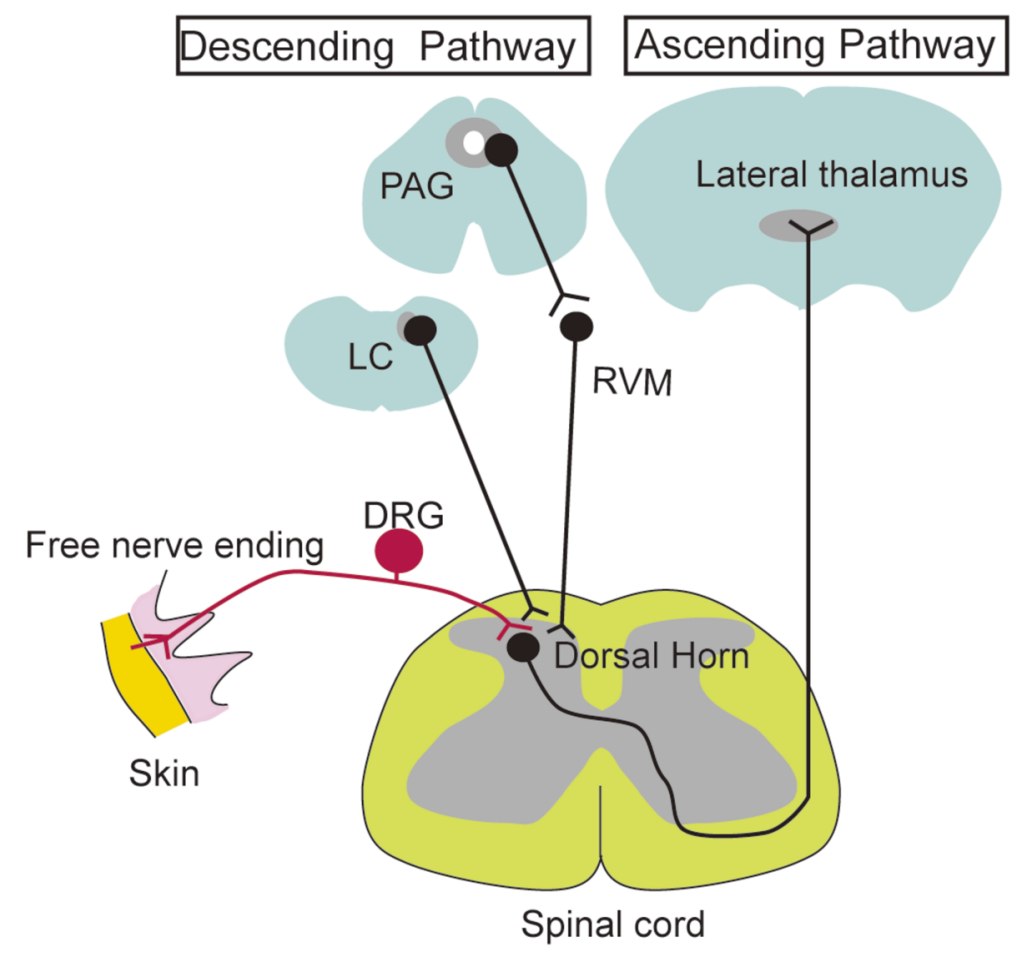

Fig. 1. Pain pathway. Ascending pathway: Pain signaling from peripheral nociceptors to thalamus via spinal dorsal horn. Descending pathway: Antinociceptive pathways from the brain to spinal cord. These pathways from PAG or LC inhibit dorsal horn neuron. PAG: periaqueductal gray, RVM: Rostral Ventromedial medulla, LC: locus coeruleus. 
tive stimuli such as heat, cold or acidic $\mathrm{pH}$. In fact, intraplantar injection of endogenous nociceptive agents such as bradykinin (1), prostaglandin E2 (2), glutamate (3), ATP (4), LPA (5), or other ligands produced nociceptive behavior against the injected region. The sources of these endogenous nociceptive agents are various cells such as injured tissues, immune cells, or free nerve endings. Furthermore, nociceptive heat or cold stimuli are able to induce pain via the TRP channel receptor families that are non-selective cation channels. For example, TRPV1 channels are activated by $\mathrm{H}^{+}$or temperature higher than $43^{\circ} \mathrm{C}$; TRPV2 channels, higher than $52^{\circ} \mathrm{C}$; TRPM8 channels, lower than $26^{\circ} \mathrm{C}$. Receptor activation causes electric activity in free nerve endings.

\section{B. Hyperalgesia and Allodynia}

Pain sensitivity is increased under various physiological or pathological conditions. In case of injury, nociceptive sensitivity is increased to prevent further tissue damage. Lower nociceptive threshold leads to recognition of tissue vulnerability and promotes protective behavior. On the other hand, it is possible that hyperalgesia or allodynia (allodynia is pain in response to a nonnociceptive stimulus such as tactile stimulus, while hyperalgesia is increased pain sensitivity) persists for long periods after tissue injury or inflammation has been resolved. In this chronic stage, pain is a disease rather than a sign of tissue damage because hyperalgesia or allodynia without tissue damage is not beneficial to prevent further tissue damage. Allodynia or hyperalgesia are produced by various mechanisms such as nociceptor sensitization, synaptic plasticity, inhibition of the descending pathway, increased spontaneous neuronal activation, and ectopic discharge. These changes are caused by pathological cases such as chronic inflammation, cancer, diabetes, and neuropathic pain. Recent studies have focused on neuropathic pain, caused by impairment of the nervous system, due to serious pain and the difficulty of therapy. Animals used in Neuropathic pain models are prepared by nerve transection or ligation. Recent studies used several ligation models: In the chronic constriction injury (CCI) model, the sciatic nerve is constricted by chromic gut; In partial sciatic nerve ligation (PSNL or Seltzer model), 1/3-1/2 of the sciatic nerves are tightly ligated by sutures; In the spinal nerve ligation (SNL) model, lumbar spinal nerve 5 (and 4/6) is ligated by sutures. Differences in these models are attributed to sensitivity against the type of nociceptive stimuli or the type of sympathetic neuron relativity.

\section{Methods of Measurement for Nociception}

Tissue injury is caused by various environmental stimuli and pain sensing is associated with diverse molecular mechanisms and neural circuits. Thus, several nociceptive stimuli are used for
一次感覚神経の自由神経終末は内在性の発痛物質や熱、 低温、酸などの侵害刺激に対する多くの受容体が存在する。 事実、内在性の発痛物質であるブラジキニン (1)、プロスタ グランジンE2(2)、グルタミン酸 (3)、ATP (4)、lysophosphatidic acid (5) などは、足底皮下に投与すると、投与した部位 に対する疼痛行動を惹起する。これらの発痛物質の供給源は 障害を受けた組織をはじめ、血球系細胞や自由神経終末など である。さらに、侵害性の熱や冷刺激は非選択的なカチオン チャネルであるTRPチャネルファミリー受容体を介して疼 痛を引き起こす。例えば、TRPV 1 は酸や $43^{\circ} \mathrm{C}$ 以上の温度で、 TRPV 2 は $52^{\circ} \mathrm{C}$ 以上、TRPM 8 は $26^{\circ} \mathrm{C}$ 以下でそれぞれ活性化さ れる。受容体の活性化は自由神経終末において電気的な活動 を引き起こす。

\section{B. 痛覚過敏およびアロディニア}

痛みの感受性は様々な生理的、あるいは病的な条件下で 増強される。負傷などのケースでは、疼痛の感受性はさらな る組織の障害を回避させるために増強する。低下した疼痛閾 值は脆弱になった組織を感知し、さらなる防御行動をとらせ る。一方で、このような痛覚過敏、あるいはアロディニア (ア ロディニアは触覚のような非侵害性の刺激に対しても痛みと して反応する現象である。一方で、痛覚過敏は痛み自体がよ り強く感じられる現象である）は炎症や障害が完治した後も 長期間持続してしまうことがある。このような慢性的な状態 では、組織障害がない痛覚過敏やアロディニアはさらなる障 害を回避するという利点がないため、痛みは障害のサインと いうよりは病態と考えたほうがふさわしい。アロデイニアや 痛覚過敏は、侵害受容器の過敏化、疼痛伝達経路のシナプス の可塑的変化、下行性疼痛抑制経路の抑制、神経繊維の自発 的あるいは異所性の発火などの多様な要因により引き起こさ れる。これらの変化は慢性的な炎症や、がん、糖尿病、神経 因性疼痛などの病態時にも観察される。最近の研究では、深 刻な痛みと治療の難しさから神経系の異常により引き起こさ れる神経因性疼痛が特に注目されている。神経因性疼痛モデ ル動物は、神経切断や神経結紮により作製される。このよう な神経因性疼痛モデルは、いくつかの種類が作製されてい る。坐骨神経絞扼（chronic constriction injury; CCI）モデルは クロムでコートした縫合糸を用いて、坐骨神経を結紮する。 坐骨神経部分結紮モデル（PNSLもしくはSeltzerモデル）で は、1/3〜 1/2 周坐骨神経を縫合糸できつく結紮する。金髄神 経結㮃（SNL）モデルでは第5（および4/6）腰椎神経を結禁 する。これらのモデルでは各種の侵害刺激に対する感受性や 交感神経からの影響が異なることが考えられている。

\section{C. 痛みの測定法}

上記のように組織障害は様々な外部の刺激により引き起 こされ、痛みの感知は多様な分子メカニズムや神経回路に関 連している。そのため、いくつかの侵害刺激が痛みの強さの 
measurement of pain intensity: the pressure of a nylon filament (von Frey filament) to the plantar surface of animals for mechanical stimulus; the placing of animals on hot plate or applying radiant heat from lamps to the plantar surface of animals which are used for measurement of thermal nociception; a cold plate for cold stimulus; and the intraplantar injection of formalin, which is used for chemical agent induced nociception. Pain intensity is measured as duration until animals show nociceptive behavior, threshold of stimulus, length of time or number of nociceptive behavior.

\section{Gangliosides Modulate Nociceptive Behaviors}

Table 1 shows several studies reporting the effects of gangliosides on nociceptive behavior including pathological pain models. As shown here, however, effects of gangliosides are different in each pain model.

\section{D-1. Gangliosides Reduced Phenylquinone-Induced Writhing}

Early studies reported systemic treatment of ganglioside mixtures $(\mathrm{GM} 1+\mathrm{GD} 1 \mathrm{a}+\mathrm{GD} 1 \mathrm{~b}+\mathrm{GT} 1 \mathrm{~b})$ reduced phenylquinone induced writhing $(6,7)$. Writhing tests are performed by measurement of time length of writhing behavior after intraperitoneal injection of harmful agents such as phenylquinone or acetic acid. Individual injection of GM1 or GT1b is more effective than GD1a or GD1b. Acetic acid writhing is used as a viscera pain model, however, mechanisms of analgesic effects of gangliosides remain unclear.

\section{D-2. Neuropathic Pain and GM1}

Intraperitoneal injection of GM1 gangliosides is reported to be reduced in thermal hyperalgesia, spontaneous nociceptive behavior observed in neuropathic pain model (CCI model) rats (8), and increased neuronal metabolic activity that is monitored by uptake of 2-deoxyglucose in spinal cord of CCI model rats (9). In addition, intrathecal GM1 injection also reduces hyperalgesia of CCI model rats (10). However, GM1 injection has no effect on thermal nociception of naive rats. These findings suggest that GM1 gangliosides are involved in nociceptive pathways in spinal cord. GM1 seems to be reduced enhanced spinal neuronal activity involved in nociceptive pathway by neuropathic pain.

\section{D-3. The Effects of GM1 on Altered Nociception in Aged Rats}

In other reports using GM1 to reduce nociception, long term treatments (daily i.p. injection for 30 days) reduce altered nociceptive behaviors of aged rats. Nociceptive behavior is changed in response to aging in rats as well as human. In the report of Goettl et al. (11), aged rats (22-24 months) showed thermal hypoalgesia and mechanical hyperalgesia compared to young rats (3-5 month). Longterm treatment of intraperitoneal GM1 administration ame-
測定に使用されている。例えば、ナイロン製のフィラメント (von Frey filament) を足底に押し当てる方法は機械的刺激に、 ホットプレート上に動物を置く、あるいはランプなどからの 放射熱を足底にあてる方法は熱刺激に、冷却されたプレート に動物を置く方法は冷刺激に、足底部皮下へのホルマリンの 注入は化学物質により引き起こされる痛みを測定するために 用いられている。痛みの強度はこれらの刺激を加えた後に疼 痛行動を引き起こすまでの時間や、刺激の強度間值、疼痛行 動を起こす時間や回数により測定される。

\section{D. ガングリオシドによる疼痛行動の調節}

Table 1 に病的な疼痛モデル動物を含む疼痛行動へのガ ングリオシドの効果を検討した報告を示す。なお、ここで示 すようにガングリオシドの効果はそれぞれの痛みのモデルで 異なる。

\section{D-1. ガングリオシド投与によるフェニルキノンWrithing の軽減}

初期の研究では、ガングリオシド混合物 $(\mathrm{GM} 1+\mathrm{GD} 1 \mathrm{a}+$ $\mathrm{GD} 1 \mathrm{~b}+\mathrm{GT} 1 \mathrm{~b})$ を全身投与することで、フェニルキノン writhing や酢酸 writhing（フェニルキノンや酢酸を腹腔内投 与すると、痛みのため身もだえするような症状を起こす）を 抑制できるという報告がある $(6,7)$ 。Writhing test は腹腔内に フェニルキノンや酢酸などの障害性の薬剤を投与し、writhing behavior（身もだえするような動き）を測定する。それぞ れのガングリオシドを個別に投与すると、GM1 や GT1bでは GD1a GD1bよりも鎮痛効果が高い。酢酸 writhing test は内 臓痛のモデルともなりうるが、ガングリオシドがどのように 痛みを抑制するか不明であった。

\section{D-2. 神経因性疼痛と GM 1}

GM1 ガングリオシドを腹腔内に投与することにより、 神経因性疼痛モデルであるCCIモデルラットで引き起こされ る熱刺激に対する疼痛過敏と自発的疼痛行動を抑制でき (8)、 CCIにより増加した脊髄の神経代謝活動（2-デオキシグル コース取り込み能）も抑制できる（9）という報告がある。さ らに、脊髄内に GM1 を投与することでCCIモデルラットの 疼痛過敏を抑制する $(10)$ 。しかし、GM1 投与は無処置動物 の熱による疼痛に対して効果を持たない。これらの結果か ら、GM1は神経因性疼痛により引き起こされた疼痛伝達系 に関わる脊髄内の神経活動の光進を抑えることで鎮痛効果を 持つと考えられる。

\section{D-3. 老化による疼痛異常における GM 1 ガングリオシドの 効果}

ほかに、GM1 を鎮痛のために投与した報告としては、 ラットにおいて GM1 を長期間処理（30日間連日腹腔内投与） したところ、老齢ラットの疼痛異常を減少させたという報告 がある。ラットの痛みの反応はヒトと同様に、老化に伴い変 化していく。Goettlらの報告では(11)、若いラット（3～5カ 月齢）に比べて高齢ラット（22２4 カ月齢）では熱に対す る感受性が低下する一方で、機械的刺激に対しては敏感にな る。長期間 GM1 を腹腔内投与することにより、高齢ラット 
Table 1. The effects of ganglioside and ganglioside related agents on pain.

\begin{tabular}{|c|c|c|c|c|c|}
\hline & & Animal model & Niciceptive stimuli & & Sensitivity \\
\hline \multicolumn{6}{|l|}{ KO mouse } \\
\hline & \multirow{3}{*}{\multicolumn{2}{|c|}{ GD3 synthase KO mice }} & von Frey filament & $\uparrow$ & Handa, Y. et al. (20) \\
\hline & & & hot plate & $\uparrow$ & \\
\hline & & & $\begin{array}{l}\text { late phase of high conc. } \\
\text { formalin }\end{array}$ & $\downarrow$ & \\
\hline \multicolumn{6}{|l|}{ Ganglioside treatment } \\
\hline GT1b i.pl. & ICR mice & & low-conc. formalin & $\uparrow$ & Watanabe, S. et al. (22) \\
\hline GT1b i.pl. & ICR mice & & spontaneous nociception & $\uparrow$ & \\
\hline Neuraminidase i.pl. & ICR mice & & $\begin{array}{l}\text { late phase of high conc. } \\
\text { formalin }\end{array}$ & $\downarrow$ & \\
\hline \multirow[t]{6}{*}{ GM1 i.p. (30 days) } & SD rats & & hot plate & $\uparrow^{*}$ & Goettl, V. M. et al. (11) \\
\hline & \multirow[t]{2}{*}{ 22-24 months } & & von Frey & $\downarrow *$ & \\
\hline & & & tail-flick test & $=$ & \\
\hline & SD rats & & hot plate & $=$ & \\
\hline & \multirow[t]{2}{*}{$3-5$ months } & & von frey & $=$ & \\
\hline & & & tail-flick test & $=$ & \\
\hline $\begin{array}{l}\text { Ganglioside mixture } \\
\text { s.c./i.p./i.v. }\end{array}$ & Swiss mice & & phenylquinone writhing & $\downarrow$ & Amico-Roxas, M. et al. $(6,7)$ \\
\hline Ganglioside mixture i.p. & Swiss mice & & hot plate & $=$ & \\
\hline GM1 i.p. & SD rats & Neuropathic pain (CCI) & radiant heat (hind paw) & $\downarrow$ & Hayes, R. L. et al. (8) \\
\hline $\begin{array}{l}\text { Brain ganglioside mix- } \\
\text { ture }{ }^{* * * * *} \text { i.p. }\end{array}$ & SD rats & Neuropathic pain (CCI) & radiant heat (hind paw) & $\downarrow$ & Mao, J. et al. (9) \\
\hline $\begin{array}{l}\text { Brain ganglioside mix- } \\
\text { ture****** i.p. }\end{array}$ & SD rats & Neuropathic pain (CCI) & spontaneous nociception & $\downarrow$ & \\
\hline GM1 i.t. & SD rats & Neuropathic pain (CCI) & radiant heat (hind paw) & $\downarrow$ & Mao, J. et al. (10) \\
\hline GM1 i.t. & SD rats & Neuropathic pain (CCI) & spontaneous nociception & $\downarrow$ & \\
\hline GM1 i.p. & 129/SvEv mice & s.c. morphin (analgesic) & tail-flick test & $\uparrow * *$ & Crain, S. M. et al. (14) \\
\hline \multirow[t]{2}{*}{ GM1 i.t. } & \multirow[t]{2}{*}{$\mathrm{SD}$ rats } & Morphine torelance i.t. & tail-flick test & $\downarrow * * *$ & Mao, J. et al. (15) \\
\hline & & $\begin{array}{l}\text { Opioid-induced } \\
\text { hyperalgesia }\end{array}$ & radiant heat (hind paw) & $\downarrow$ & \\
\hline \multicolumn{6}{|c|}{ Ganglioside binding protein } \\
\hline \multirow[t]{3}{*}{ cholera toxin B s.c. } & \multirow[t]{3}{*}{ SW mice } & $\begin{array}{l}\text { Opioid-induced hyperal- } \\
\text { gesia }\end{array}$ & tail-flick test & $\downarrow$ & Shen. K. F. et al. (12) \\
\hline & & s.c. morphin (analgesic) & tail-flick test & $\downarrow * * * *$ & \\
\hline & & Morphine torelance s.c. & tail-flick test & $\downarrow * * *$ & \\
\hline \multicolumn{6}{|l|}{ Neuraminidase inhibitor } \\
\hline \multirow[t]{3}{*}{ oseltamivir s.c. } & \multirow[t]{3}{*}{ SW mice } & $\begin{array}{l}\text { Opioid-induced hyperal- } \\
\text { gesia }\end{array}$ & tail-flick test & $\downarrow$ & Crain, M. et al. (13) \\
\hline & & s.c. morphin (analgesic) & tail-flick test & $\downarrow * * * *$ & \\
\hline & & Morphine torelance s.c. & tail-flick test & $\downarrow * * *$ & \\
\hline
\end{tabular}

\section{Ganglioside treatment}

\section{Ganglioside binding protein}

cholera toxin B s.c. $\quad$ SW mice

i.p., intraperitoneal; i.pl., intraplantar; i.t., intrathecal; i.v., intravenous; s.c., subcutaneous

$\uparrow$ indicate increased nociceptive sensitivity; $\downarrow$ indicate decreased nociceptive sensitivity; =indicate gangliosides have no significant effect on nociceptive stimuli.

*GM1 restores abnormal nociceptive responses in aged rats.

**B Blocking of opioid analgesia

$* * *$ Blocking of morphine torelances

$* * * *$ Increased duration of opioid analgesia

*****21\% GM1, 40\% GD1a, 16\% GD1b, 2\% GD3, 2\% GQ1b

liorates altered nociception of aged rats. In this injection method, GM1 has no effects on young rats. Concomitant with GM1 effects on neuropathic pain, GM1 treatment seems to restore altered pain intensity in animals to the level of naïve rats. However, the change
で変化した疼痛感受性が若年ラットに近づくようである。な お、この投与法では若年ラットには効果を持たない。神経因 性疼痛における GM1の効果とともに、GM1 は変化した痛み の強度を無処理のラットのレベルまで回復させる効果がある 
of endogenous ganglioside composition in the pain pathway is unclear.

\section{D-4. The Role of GM1 on Side Effects of Morphine}

Chronic opioid receptor agonist treatment causes tolerance and hyperalgesia. Cholera toxin B (CtxB) subunit (12) that binds to GM1, and influenza drug oseltamivir, sialidase inhibitor (13) that is expected to decreased GM1 production from higher complex gangliosides, reduced opioid induced hyperalgesia and morphine tolerance in Swiss-Webster mice. Both CtxB and oseltamivir sustain acute analgesic effects of opioids, suggesting that blocking of GM1 inhibits opioid tolerance and hyperalgesia by reducing of opioid receptor desensitization. On the other hand, analgesic effects of opioid are inhibited by GM1 treatment in $129 \mathrm{SvEv}$ mice that are resistant strain to opioid tolerance (14). It may be possible that nociceptive pathways in 129SvEv mice have low GM1 content. However, daily intrathecal injection of GM1 ganglioside could inhibit morphine tolerance and opioid induced hyperalgesia in the rat model (15). These differences may be dependent on injection methods, injected tissues and/or animal species.

Various mechanisms are involved in opioid induced hyperalgesia (16). Crain et al. suggested that G protein class coupled to the opioid receptor is changed by chronic treatment of opioids (17). Opioid receptor coupled to Gi G protein reduce cAMP levels and neuronal activity under a normal state. Chronic opioid treatment may induce switching from Gi to Gs which induced cAMP production and neuronal activation. Indeed, chronic treatment of F11 cells (neuroblastoma $\times$ DRG neuron hybrid cells) with [D$\left.\mathrm{Ala}^{2}, \mathrm{D}-\mathrm{Leu}^{5}\right]$-Enkephalin (DADLE), a $\delta$ opioid receptor agonist, increased cAMP levels although $\delta$ opioid receptors are coupled to a Gi G protein under normal state. Acute DADLE treatment does not cause cAMP production, however, pretreatment of GM1 cause cAMP production by acute DADLE treatment in F11 cells. In addition, GM1 pretreatment abolish inhibitory effects of DADLE on forskolin induced cAMP production (18). Furthermore, using NG108-15 cells, co-treatment with DADLE, GM1 and pertussis toxin that inhibit Gi activation, lead to enhanced cAMP production (19), indicating that GM1 enhanced opioid receptor coupling to Gs protein under inhibition of Gi activation.

\section{D-5. Ganglioside Biosynthesis Enzyme Knockout Mice and Nociception}

GD3 synthase deficient mice showed significant nociceptive defects (20) without visible histological defects in the nervous system (21), significant differences in the conduction velocity and the size of the cross-sectional area of the myelinated axons in the sciatic nerve (20). Nociceptive behavior of these $\mathrm{KO}$ mice is conflicting; KO mice showed mechanical allodynia (using von Frey filament), thermal hyperalgesia (hot plate) and reduced nociceptive
ようである。しかし、疼痛伝達系における内在性のガングリ オシドの組成変化は不明である。

\section{D-4. モルヒネの副作用におけるGM 1 の役割}

オピオイドは慢性的に作用させることで耐性が生じ、同 時に痛覚過敏を引き起こす。GM1に結合するコレラトキシ ン B (CtxB) サブユニット (12) や、インフルエンザ治療薬 oseltamivir(13)（シアリダーゼ阻害薬であり、高級ガングリ オシドからのシアル酸分解による GM1 産生を抑制すること が期待される）はSwiss-Websterマウスにおいて、オピオイ ドによる耐性と痛覚過敏を抑制することが報告されている。 さらに、CtxB、oseltamivirともに急性的なオピオイドによる 鎮痛効果を持続させるため、GM1 をブロックすることでオ ピオイド受容体の脱感作を抑制し、オピオイド耐性や痛覚過 敏を抑制するということが示唆される。一方で、オピオイド 耐性が生じにくい系統である 129SvEv マウスにGM1を投与 すると、オピオイドの鎮痛効果を抑制する (14)。129SvEv マ ウスの疼痛伝達経路においては GM1 量が少ない可能性があ る。しかし、連日の脊髄への GM1 ガングリオシド投与によ りラットモデルにおいてモルヒネ耐性や痛覚過敏が抑制され る $(15)$ 。これらの効果の違いは投与方法や投与組織、動物種 などの違いに起因するかもしれない。

オピオイドによる痛覚過敏は多様な要因により引き起こ される (16)。Crainらはオピオイド受容体に共役する G夕ン パク質のクラスがオピオイドの慢性投与により変化する可 能性を示している(17)。オピオイド受容体は通常 Gi タンパ ク質と共役することにより、cAMPを抑制し神経の活動を抑 制する。慢性的なオピオイド投与により、Giから Gsへの共 役が進みcAMPを産生するようになることで疼痛伝達経路の 神経細胞がオピオイドにより興奮性を生じるというメカニ ズムである。実際、F11細胞 (neuroblastoma と DRGニュー ロンのハイブリッド細胞）に $\delta$ オピオイド受容体のアゴニス ト $\left[\mathrm{D}-\mathrm{Ala}^{2}, \mathrm{D}-\mathrm{Leu}^{5}\right]$-Enkephalin (DADLE) を長期に投与する と、通常状態では Gi と共役しているにもかかわらず cAMP の上昇が観察される。一過性にDADLE処理をしても cAMP は生産されないが、GM1をあらかじめ投与しておくと一過 性のDADLE処理により cAMPが産生される。加えて、GM1 はDADLEによるホルスコリン誘導 $\mathrm{cAMP}$ 産生の抑制を解除 する(18)。さらに、神経芽細胞NG108-15を用いて、GM1 と 百日咳毒素存在下（Gi の活性化を阻害する）で、低濃度の DADLEを処理するとcAMPを産生する(19)。これらの結果 は、GM1 はGiが阻害される条件下ではオピオイド受容と Gs の共役を増強することを示唆している。

\section{D-5. ガングリオシド生合成酵素ノックアウトマウスと疼} 痛

GD3 合成酵素ノックアウトマウスは、疼痛異常を示す (20)。このマウスは目に見える組織学的な神経系の異常を示 さず(21)、坐骨神経の伝導速度や有髄軸索の横断面の面積も 異常を示さない $(20)$ 。しかしながら、疼痛異常の解釈は複雑 であるかもしれない。つまり、このノックアウトマウスは機 械刺激（von Frey filament）および熱（ホットプレート）に 対する痛覚過敏を示すが、ホルマリンによる疼痛の第二相に 
behavior in the late phase of formalin test. These conflicting results may be due to several causes: GD3 synthase KO mice have the depletion of b- and c-series gangliosides and accumulation of a-series gangliosides. Thus, it is unclear whether depleted gangliosides or accumulated gangliosides affect altered nociceptive behavior: each ganglioside species may relate a particular nociceptive stimulus and/or each tissue in pain pathway.

\section{D-6. b-Series Ganglioside and Nociception}

We reported that intraplantar injection of GT1b induced nociceptive behavior and hyperalgesia of low-dose formalin induced nociception (22). Hyperalgesic effects of ganglioside such as GQ1b, GT1b, or GD1b were observed, although a-series gangliosides such as GD1a, GM1, GM2 or GM3 had no significant effects in nociception induced by intraplantar injection of low-dose formalin. In addition, intraplantar injection of Arthrobacter ureafaciens sialidase that cleaves $\alpha 2 \rightarrow 3, \alpha 2 \rightarrow 6$ and $\alpha 2 \rightarrow 8$ linked sialic acids reduced the late phase of high-dose formalin induced nociception as observed in GD3 KO mice. These data supported the possibility that endogenous gangliosides in subcutaneous tissues contribute to nociceptive behavior. Next, we tried to identify the receptors against nociceptive agents involved in GT1b-induced hyperalgesia by using several receptor antagonists. Among the tested antagonists, antagonists against NMDA receptor and mGluR1, but not other antagonists against pain-related receptors such as 5-HT2A, 5-HT3, histamine H1, purine P2, prostaglandin EP4, and bradykinin B2, blocked GT1b- induced hyperalgesia. Moreover, intraplantar injection of GT1b caused glutamate accumulation in subcutane-

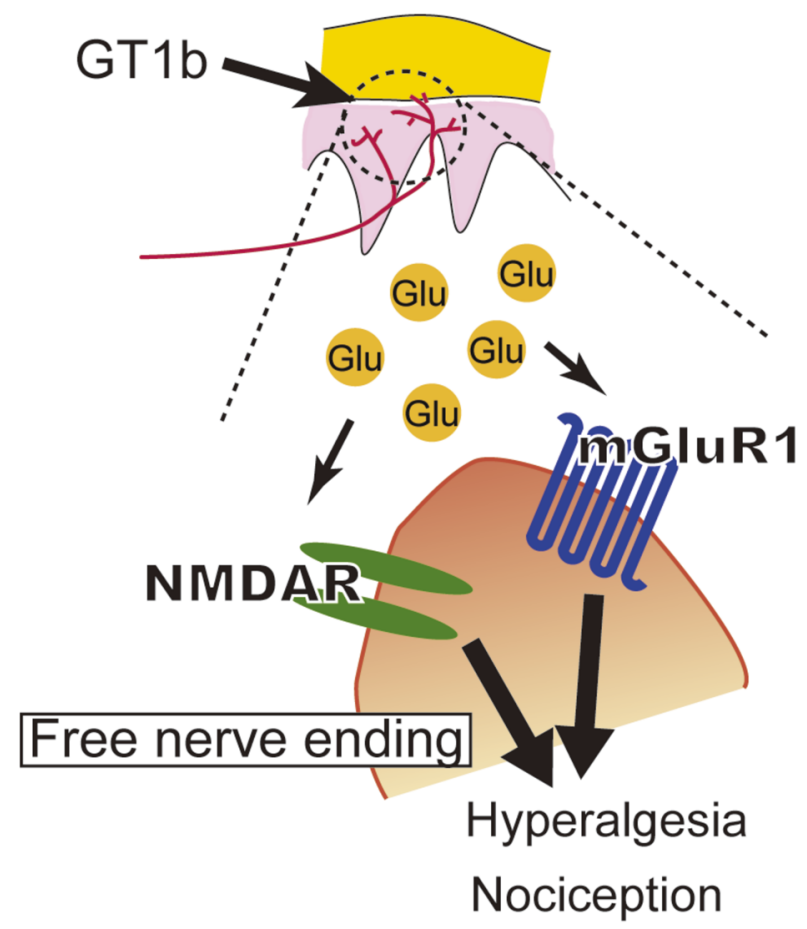

おいて疼痛行動は減少する。これらの相反した結果はいくつ かの原因によるのかもしれない。GD3 合成酵素ノックアウ トマウスではb-およびc-シリーズガングリオシドが久損し、 a-シリーズガングリオシドは蓄積している。そのため、蓄積 したガングリオシドと欠損したガングリオシドのどちらが疼 痛異常をもたらしているのか明らかでない。それぞれのガン グリオシド種と、特定の侵害刺激や疼痛伝達経路の各組織が 関連しているのかもしれない。

\section{D-6. b-シリーズガングリオシドと痛み}

筆者らはマウス足底皮下にガングリオシド GT1bを投与 すると疼痛行動を引き起こし、低濃度のホルマリンにより引 き起こされる痛みに対して痛覚過敏効果が認められることを 見いだした $(22)$ 。低濃度ホルマリンに対する痛覚過敏作用 はb-シリーズのガングリオシドである GQ1b、GT1b、GD1b においては有意に認められたが、a-シリーズガングリオシド GD1a、GM1、GM2、GM3では認められなかった。さらに、 Arthrobacter ureafaciens シアリダーゼ（ $\alpha 2 \rightarrow 3 、 \alpha 2 \rightarrow 6 、 \alpha 2 \rightarrow 8$ 結合をいずれも切断する）をホルマリンの投与部位（足底皮 下）に前投与することにより、GD3ノックアウトマウスで 観察されたようにホルマリンによる第二相の疼痛が減弱する 現象が認められた。これらのデータは、皮下組織において内 在性ガングリオシドが疼痛に寄与している可能性をサポー トしている。次に、GT1bによる痛覚過敏に関与している皮 下における発痛物質に対する受容体を、そのアンタゴニス トにより決定することを試みた。検討した受容体アンタゴ ニストの中で、NMDA受容体や mGluR1のアンタゴニストの みが GT1bによる痛覚過敏効果をブロックし、ほかのアンタ ゴニスト（5-HT2A、5-HT3、histamine H1、 purine P2、prostaglandin EP4、bradykinin B2 受容体アンタゴニスト）では有
Fig. 2. Glutamate is released by GT1b treatment in subdermal tissues. Intraplantar injection of GT1b caused hyperalgesia, nociception, and glutamate accumulation in subcutaneous tissue. Co-injection of glutamate degrading enzyme or glutamate receptor antagonists with GT1b blocked GT1b-induced hyperalgesia. These findings suggested that GT1b increased extracellular glutamate levels in subdermal tissues, thereafter activating glutamate receptors, which in turn, resulted in hyperalgesia and nociception. 
ous tissue and glutamate dehydrogenase (GLDH), which degrades glutamate, blocked GT1b-induced hyperalgesia. These results indicate that GT1b is involved in regulation of extracellular glutamate concentrations in subcutaneous tissue, which leads to glutamate receptor activation and then induces hyperalgesia (Fig. 2).

Previous reports revealed glutamate in subcutaneous tissues is involved in nociceptive behavior. Nociceptive stimuli such as heat, capsaicin (23), and formalin (24) leads to glutamate accumulation in subcutaneous tissues. In fact, intraplantar injection of glutamate or glutamate receptor agonists induce nociceptive behavior (3, 25-27). This glutamate in subcutaneous tissue is released from Aor C-fiber by electrical stimulation of peripheral nerve fibers (28). Moreover, recent immunohistochemical studies revealed that vesicular glutamate transporters (vGluTs) are localized in free nerve endings (29). These studies suggest a glutamate source in subcutaneous tissue may be free nerve endings. Thus, it is possible that GT1b are involved in glutamate releasing systems of free nerve endings (Fig. 2).

Recently, we reported that gangliosides are involved in painrelated receptors. Pretreatment of cells with gangliosides and/or chondroitin sulfate potentiate bradykinin B2 receptor desensitization and internalization (30). Bradykinin is a potent endogenous nociceptive agent, and future studies are needed to reveal the effects of gangliosides in bradykinin-induced nociception using animal models.

\section{E. Conclusion}

As mentioned above, gangliosides can regulate various nociception such as neuropathic pain, altered pain in aging animals, opioid-induced hyperalgesia, morphine tolerance, and formalin induced nociception. These studies present a novel gangliosidedependent mechanism of pain. However, its molecular mechanisms have not been clarified and the effects of gangliosides on nociceptive behavior may be dependent on various conditions such as nociceptive models, injected site, or carbohydrate structures. In fact, GD3 synthase knockout mice show both thermal hyperalgesia and hypoalgesia on formalin induced nociception. However, there are few examples that compare the differences in effect of ganglioside using the same nociceptive stimulus in the same nociceptive model.

Future studies are needed to reveal these problems, especially, the relationship between molecular structures of gangliosides and nociceptive responses under each pathological state.
意な効果が認められなかった。さらに、皮下において GT1b の投与によりグルタミン酸の蓄積が生じることや、glutamate dehydrogenase（GLDH、グルタミン酸を分解する）の共投与 により GT1bの疼痛増強効果を抑制した。以上の結果から、 GT1bが皮下における細胞外グルタミン酸濃度の制御に関与 し、これによりグルタミン酸受容体を活性化することで痛覚 過敏を引き起こすことが示唆される（Fig. 2）。

以前の研究から、皮下における細胞外グルタミン酸は 疼痛に関与していることが明らかになっている。皮下にお けるグルタミン酸の濃度は熱やカプサイシン $(23)$ 、あるい はホルマリン (24) といった疼痛刺激により増加する。実際 に、グルタミン酸やグルタミン酸受容体アゴニストをマウス の足底皮下に投与すると、疼痛行動を引き起こす $(3,25-27)$ 。 皮下におけるグルタミン酸は末梢の A-繊維やC-繊維を電気 的に刺激することで分泌される $(28)$ 。さらに、組織学的に vesicular glutamate transporters（vGluTs）が自由神経終末付近 に存在していることが明らかにされている(29)。以上の報告 から、皮下におけるグルタミン酸源の一つは自由神経終末で あるかもしれない。そのため、GT1bは自由神経終末におけ るグルタミン酸放出経路に関与している可能性が考えられる (Fig. 2)。

最近、我々は疼痛受容体とガングリオシドの関連性を示 唆する研究結果を得た。ブラジキニン B 2 受容体を発現させ た培養細胞にガングリオシドやコンドロイチン硫酸を投与す ると、受容体の不応化と内在化が促進されたのである $(30)$ 。 ブラジキニンは強力な内在性の発痛物質であり、今後、動物 モデルを利用してブラジキニンにより引き起こされる疼痛に おけるガングリオシドの効果を明らかにする必要がある。

\section{E. 結語}

以上のように、神経障害性疼痛や、老齢により変化した 疼痛感受性、オピオイドによる痛覚過敏、モルヒネ耐性、ホ ルマリンによる疼痛など様々な痛みをガングリオシドは制御 できる。これらの報告はガングリオシド依存的な何らかの新 規なメカニズムが疼痛に関与していることを示唆する。しか し、その分子メカニズムはいまだ明らかではなく、疼痛行動 におけるガングリオシドの効果は疼痛モデルや投与部位、あ るいはガングリオシドの糖鎖構造に依存しているかもしれな い。事実、GD3 合成酵素ノックアウトマウスは熱による痛 覚過敏とホルマリンに対する痛覚鈍麻の両者を示す。しかし ながら、ガングリオシドの効果の違いを同一の疼痛刺激や疼 痛モデルで比較した例はほとんど知られていない。

今後の研究は特に、それぞれの病的な状態におけるガン グリオシドの分子構造の違いと疼痛反応の関連性を検討する ことが必要である。 


\section{References}

1. Ferreira, J., Triches, K. M., Medeiros, R., and Calixto, J. B. (2005) Pain 117, 171-181.

2. Kassuya, C. A., Ferreira, J., Claudino, R. F., and Calixto, J. B. (2007) Br. J. Pharmacol. 150, 727-737.

3. Beirith, A., Santos, A. R., and Calixto, J. B. (2002) Brain Res. 924, 219-228.

4. Bland-Ward, P. A., and Humphrey, P. P. (1997) Br. J. Pharmacol. 122, 365-371.

5. Renback, K., Inoue, M., Yoshida, A., Nyberg, F., and Ueda, H. (2000) Brain Res. Mol. Brain Res. 75, 350-354.

6. Amico-Roxas, M., Caruso, A., Cioni, M., Scifo, R., Leone, M. G., and Scapagnini, U. (1988) Arch. Int. Pharmacodyn. Ther. $291,238-252$.

7. Amico-Roxas, M., Caruso, A., Trombadore, S., Scifo, R., and Scapagnini, U. (1984) Arch. Int. Pharmacodyn. Ther. 272, $103-117$.

8. Hayes, R. L., Mao, J., Price, D. D., Germano, A., d’Avella, D., Fiori, M., and Mayer, D. J. (1992) Pain 48, 391-396.

9. Mao, J., Hayes, R. L., Price, D. D., Coghill, R. C., Lu, J., and Mayer, D. J. (1992) Brain Res. 584, 18-27.

10. Mao, J., Price, D. D., Hayes, R. L., Lu, J., and Mayer, D. J. (1992) Brain Res. 584, 28-53.

11. Goettl, V. M., Lindsey, A. E., Neff, N. H., and Hadjiconstantinou, M. (2000) Brain Res. 858, 380-385.

12. Shen, K. F., and Crain, S. M. (2001) Brain Res. 919, 20-30.

13. Crain, S. M., and Shen, K. F. (2004) Brain Res. 995, 260-266.

14. Crain, S. M., and Shen, K. (2000) Brain Res. 856, 227-235.

15. Mao, J., Price, D. D., and Mayer, D. J. (1994) J. Neurosci. 14, 2301-2312.

16. Koppert, W., and Schmelz, M. (2007) Best Pract. Res. Clin. Anaesthesiol. 21, 65-83.

17. Crain, S. M., and Shen, K. F. (1998) Trends Pharmacol. Sci. 19, 358-365.

18. Wu, G., Fan, S. F., Lu, Z. H., Ledeen, R. W., and Crain, S. M. (1995) J. Neurosci. Res. 42, 493-503.

19. Wu, G., Lu, Z. H., Alfinito, P., and Ledeen, R. W. (1997) Neurochem. Res. 22, 1281-1289.

20. Handa, Y., Ozaki, N., Honda, T., Furukawa, K., Tomita, Y., Inoue, M., Furukawa, K., Okada, M., and Sugiura, Y. (2005) Pain 117, $271-279$.

21. Okada, M., Itoh, M.-i., Haraguchi, M., Okajima, T., Inoue, M., Oishi, H., Matsuda, Y., Iwamoto, T., Kawano, T., Fukumoto, S., Miyazaki, H., Furukawa, K., Aizawa, S., and Furukawa, K. (2002) J. Biol. Chem. 277, 1633-1636.

22. Watanabe, S., Tan-No, K., Tadano, T., and Higashi, H. (2011) Pain 152, 327-334.

23. Jin, Y. H., Nishioka, H., Wakabayashi, K., Fujita, T., and Yonehara, N. (2006) Neuroscience 138, 1329-1339.

24. Omote, K., Kawamata, T., Kawamata, M., and Namiki, A. (1998) Brain Res. 787, 161-164.

25. Omote, K., Kawamata, T., Kawamata, M., Nakayama, Y., Hazama, K., and Namiki, A. (2000) Anesthesiology 93, $173-178$.

26. Bhave, G., Karim, F., Carlton, S. M., and Gereau, R. W. 4th. (2001) Nat. Neurosci. 4, 417-423.

27. Zhou, S., Bonasera, L., and Carlton, S. M. (1996) Neuroreport 7, 895-900.

28. deGroot, J., Zhou, S., and Carlton, S. M. (2000) Neuroreport 11, 497-502.

29. Brumovsky, P., Watanabe, M., and Hokfelt, T. (2007) Neuroscience 147, 469-490.

30. Shimazaki, A., Nakagawa, T., Mitoma, J., and Higashi, H. (2012) Biochem. Biophys. Res. Commun. 420, 193-198.

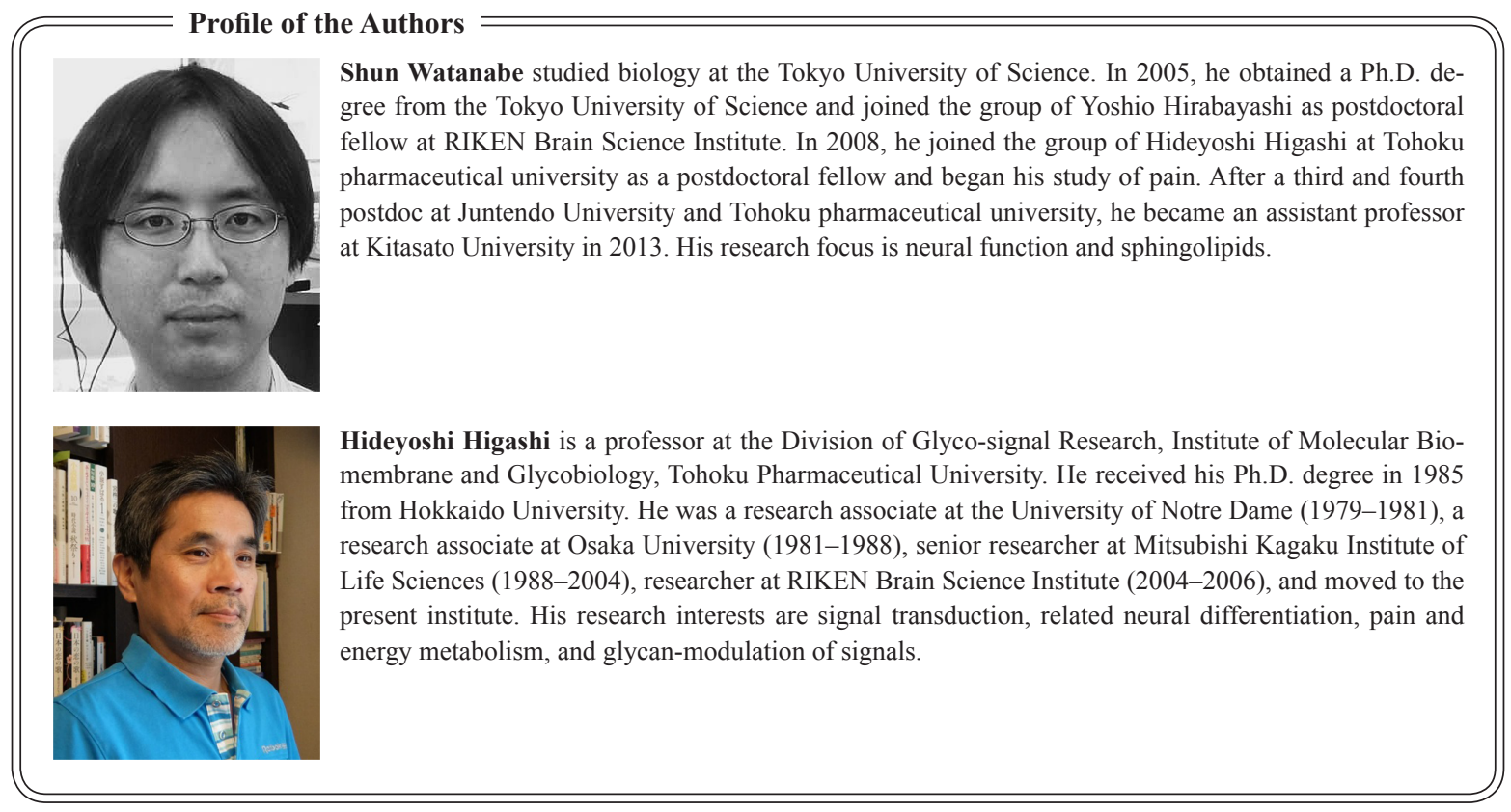

